Article

\title{
Creating the Conditions for Climate Resilience: A Community-Based Approach in Canumay East, Philippines
}

\author{
Corrine Cash \\ Department of Geography and Environment, Mount Allison University, Canada; E-Mail: ccash@mta.ca
}

Submitted: 19 May 2021 | Accepted: 19 July 2021 | Published: 16 December 2021

\begin{abstract}
People who reside in informal settlements in the Global South are most vulnerable to extreme weather events and their consequences, such as flooding, landslides, and fires. Those located in coastal areas face severe challenges from seasonal and typhoon-induced flooding. Research shows that uncertain land rights exacerbate community vulnerability because residents are under constant threat of eviction by private sector actors or the state. Individual and community upgrading is rarely possible in such a situation. This article focuses on the efforts to secure tenure and upgrade their community by the residents of Sitio Libis, located in Canumay East, City of Valenzuela, Philippines. The study demonstrates that while community-based approaches require skills and capacities of community members, enabling conditions created by government and/or NGOs are required for transformational outcomes. While the people of Sitio Libis did not conceptualize their efforts in terms of climate change adaptation, their success suggests the possibility for smart partnerships among state-civil society/private sector actors to emerge in support of small-scale climate action.
\end{abstract}

\section{Keywords}

climate change; climate justice; community-based adaptation; informal settlements; just city; Manila; re-blocking; social equity

Issue

This article is part of the issue "Planning for the Local Impacts of Climate Change: Nobody Left Behind?" edited by Mark Seasons (University of Waterloo, Canada).

(C) 2021 by the author; licensee Cogitatio (Lisbon, Portugal). This article is licensed under a Creative Commons Attribution 4.0 International License (CC BY).

\section{Participatory Development and the Right to the City}

The belief that citizen-led, community-based approaches will result in positive developmental outcomes is persistent across disciplines and issue areas (Dale et al., 2020; Lang et al., 2020; Mathie \& Cunningham, 2008; Westoby et al., 2020). Participatory theories and methods emerged in the 1960s in response to failed and/or contested projects undertaken worldwide in the postWorld War II era of international development (Arnstein, 1969; Chambers, 1983). Most of the focus across the Global South was on rural development, giving rise to methods such as the participatory rural appraisal and farmer-to-farmer learning (Gonsalves et al., 2005). In the 1980 s and 90s, this perspective shifted to include urban areas as neoliberal globalization restructured the capitalist world economy contributing to the emer- gence of mega-cities across the Global South (Brenner \& Theodore, 2002; Sassen, 1991, 2002; Tadiar, 2013). One consequence of this global transformation was the rise of slums and what Ravallion et al. (2007) describe as the "urbanization of poverty." Thus, participatory urban appraisal emerged as a technique for addressing community-based problems particularly in slums and informal settlements.

Nonetheless, what is to be done, by and for whom, particularly in relation to urban poverty, remains a highly contested topic (Holland \& Blackburn, 1998). "Bottom-up" approaches stand in stark contrast to the persistence, even dominance in many countries, of "top-down" approaches to land use planning. Planning practice originated in top-down decisionmaking approaches that may be attributed to planners such as Robert Moses and Ebenezer Howard. Prior to 
the 1970s, planning decisions were made by a group of experts who believed that they knew what was best for a community and imposed their plans accordingly. Remarkably, the mainstream of urban design continues to draw on ideas such as the concentric zone modelnow almost 100 years old-and assess cities around the world in terms of Western ideas of "best practice" (Park et al., 1925; for the critique see, e.g., Appadurai, 2002; Roy, 2009; Simone, 2005, 2008, 2010).

In line with broader developmental trends, multiple planning professionals promoted more participatory models. For example, John Friedmann introduced transactive planning while Paul and Linda Davidoff's advocacy planning emerged at this time. One of the most well-known tools for assessing community engagement within a planning project is Arnstein's (1969) ladder of citizen participation. Arnstein's ladder had eight steps, moving from no citizen control to effective empowerment: (1) manipulation and (2) therapy, which together constitute "non-participation"; (3) informing, (4) consultation, and (5) placation, which together constitute various degrees of tokenism; (6) partnership, (7) delegation, and (8) citizen control, which mark varying degrees of citizen power. Numerous derivations of this model have emerged over time (Cornwell, 2008; Pretty, 1995; White, 1996). Pretty (1995, p. 1252), for example argues that "self-mobilization," as the highest rung on the ladder, means that:

People participate by taking initiatives independently of external institutions to change systems. They develop contacts with external institutions for resources and technical advice they need, but retain control over how resources are used. Selfmobilization can spread if government and NGOs provide an enabling framework of support. Such selfinitiated mobilization may or may not challenge existing distributions of wealth and power.

Community-based adaptation (CBA) approaches, which emerged largely from climate change and development practice, would be situated at the "citizen control" end of the ladder. In CBA, community members drive the entire planning process-from conception to implementation to evaluation. Community members may draw on the expertise of others but the desire to do so comes from them-not from an outside entity or person. "Community-based adaptation to climate change is a community-led process, based on communities' priorities, needs, knowledge, and capacities, which should empower people to plan for, and cope with, the impacts of climate change" (Reid et al., 2009, p. 13). Rather than an outsider pointing out the deficits within a community, members themselves identify actions that they wish to take to improve their community and to increase its security in light of climate threats and hazards. Ultimately, CBA approaches acknowledge the expertise that exists within a community and begin at the local level to build on these strengths. However, it must be noted that CBA approaches are not without their critiques. For example, Titz et al. (2018) have argued that, if one is not careful, the notion of community may be romanticized, with existing power imbalances ignored. Dodman and Mitlin (2013, p. 650) have argued that CBA "accepts rather than questions the underlying political economic processes that have contributed to the growing climate crisis and adaptation deficit." Of course, these criticisms are not new and reflect challenges of scale-temporal as well as spatial-and perspective-both practical and ideological (Chambers, 1983; Fainstein, 2009; Marcuse, 2009).

This seemingly universal tension between top-down versus bottom-up planning is exacerbated by the nature of the post-colonial state across most of the Global South (Hansen \& Stepputat, 2001). The colonial state was a highly centralized means for often violent social control and economic extraction. This hierarchical structure persisted into the post-colonial period and manifested most clearly in centralized national development plans, policies, and programs. Far from including citizens as participants in the planning process, these affairs were, and in many cases continue to be, negotiated between central state authority and external actors such as the World Bank, the International Monetary Fund, the European Union, and various inter-governmental organizations as well as multinational corporations. The Philippines under the 21-year dictatorial rule of Ferdinand Marcos (1965-1986) typifies this situation. During his tenure as president, Marcos waged a war against the urban poor, turning to heavy-handed tactics of slum clearance and forced eviction sometimes masqueraded behind concepts such as "city beautification" and balik probinsya ("back to the countryside"). Dominant narratives of "congestion," "overcrowding," and "disease" were used to justify demolition of informal settlements and citizens' displacement to rural areas (UN-Habitat, 2018).

This raises questions of what is a city and who is it for? At about the time Arnstein was devising her ladder of participation, Lefebvre (1968a, 1968b) was articulating his idea of "the right to the city." While Lefebvre's initial conception of the right to the city was philosophical and idealistic, it has taken on more pragmatic characteristics in subsequent decades. Harvey (1985) used it in support of his argument against neoliberal "accumulation by dispossession," with gentrification being one clear urban manifestation of this concept. Similar leftist critiques of neoliberal globalization and its impact on people, places, and things can be seen in the work of Mitchell (2003), Simone (2005), and Marcuse (2009). Specifically in relation to cities, Castells (1983) and Smith $(1979,1984)$ highlighted the importance of urban social movements, recognizing that urban development is unavoidably (and possibly necessarily) a conflictual process. Slater (2009) highlights how "the right to the city" has in fact become a rallying cry for marginalized community-based organizations. Brown (2013) contrasts the philosophical (e.g., Lefebvre) and practical (e.g., 
Slater)-both of which emerge out of Marxist, socialist, and feminist perspectives of equity and inclusionwith the liberal, human rights-oriented approach taken by inter-governmental organizations such as UN-Habitat and UNESCO. The liberal perspective is often criticized by the Left as re-centralizing urban planning, moving back down Arnstein's ladder toward, at best, consultation. Nevertheless, and as will be demonstrated in the case study below, the idea of a "right to the city" creates common ground for highly differentiated actors: from local community-based organizations to global social movements; from municipal, state, and federal government organizations to national banks, international financial institutions, and cooperative associations. These are strange bedfellows, but they coalesce around common purpose-i.e., slum-upgrading-through the discourse of stakeholder participation in support of a right to the city. As shown below, the outcomes in support of CBA in Sitio Libis align with Pretty's observation regarding selfmobilization as well as Fainstein's notion of "just cities," which Ninglekhu and Rankin (2017, p. 264) describe as marking a choice of "pragmatics of the socially just capitalist city over the unattainable utopia of the socialist city."

\section{Methodology}

The initial intent of the project upon which this study is based was to engage in a peer-to-peer learning experience which would bring together individuals from the Homeless People's Federation of the Philippines Inc. (HPFPI) and people from Slum Dwellers International (SDI) in Sierra Leone to share experiences. The intent was for people in Sierra Leone to learn how those in the Philippines had success in purchasing the land in which they lived, engaged in re-blocking, and implemented climate adaptation measures. Step one was to involve the Sierra Leone group to travel to the Philippines to meet with leaders from HPFP and to visit the communities. However, the individuals from Sierra Leone were not granted visas and the project had to be altered. The initial question was to address scalability of the Philippines model. This study draws on the research conducted for the original study but combines it with a critical analysis of secondary sources to reflect on the potential for citizen-based action to form a foundation for meaningful climate change adaptations.

Participatory action research was utilised in this study wherein community members assisted with the collection of data. Specifically, participants led discussions with community members, used video and photographs to collect data, and led community tours, allowing for questions and answers to develop with community members. One of the benefits of participatory action research is that "participants have special access to how social and educational life and work are conducted in local sites by virtue of being insiders" (Kemmis et al., 2013, p. 5).
SDI facilitated the community entry point as they have had an existing partnership with the HPFPI for many years. The HPFPI created the link between the researchers and the head of the Sitio Libis, who accompanied and participated in all elements of the research with the external researchers.

In addition to the data collected in collaboration with community members, there were four focus groups with experts such as a lawyer, government officials, youth, and community members. A snowballing technique was used whereby one interview or conversation led to another. This often occurred during the transect walks and informal conversations that occurred throughout the research. Grey material was reviewed and was often gathered throughout the snowballing process. All interviews, videos, photographs, grey literature review, and review of official documentation (website searches of policies, plans, and existing peer-reviewed papers) were triangulated.

\section{Study Area}

\subsection{Background and Context}

The Republic of the Philippines consists of 7,641 small islands in Southeast Asia and covers a landmass of 300,000 square kilometers (Government of the Philippines, 2021b). The Global Climate Risk Index (Eckstein et al., 2021, p. 13) ranks the country as fourth most vulnerable in the world over the first two decades of the 21st century (behind Puerto Rico, Myanmar, Haiti, and ahead of Mozambique, The Bahamas, and Bangladesh). Over this time period, the Philippines recorded 317 extreme events, considerably more than Nepal (191) and Bangladesh (185) in second and third place respectively. The World Risk Report (Bündnis Entwicklung Hilft, 2018) placed the Philippines third, behind Vanuatu and Tonga.

In Metro Manila, the level of risk is even higher than that of the country as a whole. Unchecked and largely unplanned growth over several decades has heightened vulnerability by supplanting the natural environment (thereby eliminating nature-based solutions) with a built environment that exacerbates the negative impacts of extreme events at every turn. Valenzuela City is a good example of this as over decades the low-lying delta area was first drained and turned into farmland, then populated by both light and heavy industry which inevitably attracted migrants in search of economic opportunity leading to the expansion of both formal and informal housing.

Valenzuela City constitutes one part of an area designated as KAMANAVA, i.e., the geographical extent of four cities at the northern tip of Metro Manila: Caloocan, Malabon, Navatos, and Valenzuela. This entire area is an estuarine environment, generally below five metres above sea level (masl), a considerable amount of which is below the high tide line. According to Porio (2014, p. 85): 
The KAMANAVA flood basin is particularly susceptible throughout the year to the effects of sea-level rise and tidal storms. During the last few years, the residents have reported changes in the climate patterns marked by increases in sea levels during tidal/storm surges, as reflected in the water marks left in their house posts.

There are three rivers that pass in and around Valenzuela City: Tullahan, Pole, Meycauayan.

Climate change is increasing the intensity of typhoons (IPCC, 2014) and sea level rise will especially impact the Philippines, causing coastal erosion and land loss, inundation and sea flooding, upstream movement of the saline/freshwater front, and seawater intrusion into freshwater lenses (IPCC, 2020). Studies show that millions of people will be displaced from South Asian coastal zones, assuming a one-meter rise in sea levels. According to the Government of the Philippines (2021a), climate change also creates threats to biodiversity and food security, and endangers vulnerable groups such as women, children, indigenous people, and the poor.

\subsection{Sitio Libis, Canumay East, City of Valenzuela}

In the 1960s, the Philippines experienced mass migration of rural citizens into urban areas. However, urban areas did not have the infrastructure, housing, or capacity to adequately contain the influx of people. In 1970, 31.8\% of the population lived in urban areas, rising to $37.5 \%$ in 1980 (Republic of the Philippines, 1991). As of 2015, the urban population sat at $51.2 \%$ (Philippines Statistics Authority, n.d.). Over the same period, the total population of the Philippines increased from 35 million to more than 110 million, with Metro Manila's population growing from 3.97 million to 14.16 million, of which an estimated 3 million live in informal settlements. According to the World Bank (2021), in 2018, $43 \%$ of the population of the Philippines lived in slums.

The urban poor have few choices for improving their situation. In the words of urban specialist Mike Davis:

With land inflation raging even on the distant urban edge, the only choices seemingly left to the poorest Manilenos are either to risk death in the flood-prone metropolis by squatting in the beds of esteros or along the precarious banks of rivers, or to occupy the interstices of wealthier barangays where violent eviction is an imminent threat. (La Viña, 2017).

Without secure land, housing, and properly serviced communities, the poor survive in a never ending, unbreakable poverty cycle:

Hundreds of thousands of urban poor households in the Philippines live on land that does not belong to them and they suffer the constant threat of being displaced. In addition, many live in informal settlements on dangerous sites-for instance on dump sites, along railroad tracks, under bridges and on riverbanks, shorelines, low-lying areas and critical slopes. (Teodoro \& Rayos Co, 2009, p. 415)

Sitio Libis sits within Canumay East (population 50,000), a barangay of the City of Valenzuela (population 569,000 ). Sitio Libis is comprised of an estimated 342 families, the first of whom arrived in the area in the 1970s. In 2010, the community came together to form the United Libis Homeowners Association (ULHOA). Theresa Carampatana serves as Association President. Average floor space per family in the informal settlement is 28 square meters. The entire settlement is 15,688 square meters, was built on land owned by the Philippines Veterans Bank, and is bordered entirely by industrial enterprise.

The relative success of the people of Sitio Libis in securing land tenure, and thus the right to improved livelihoods, cannot be understood outside of the particular governance setting. As the challenges of slum dwelling increased over the last fifty years, so too has the changing political landscape created opportunities for positive change. As shown below, dramatic legal, institutional, and organizational changes created an enabling environment perhaps unique to the Philippines.

\subsection{Changing Forms of National Governance}

During President Ferdinand Marcos' era (1965-1986), squatting was illegal and those who lived in informal settlements were considered as criminals. Presidential Decree 772 imposed a penalty of imprisonment for six months to one year for those guilty of squattingthose who "unlawfully encroach on public and private land without the express consent of the landowner" (UN-Habitat, 2018, p. 50).

In 1986, the newly elected President Corazon C. Aquino aimed to reverse oppressive practices enforced during the 20 years of rule by President Ferdinand Marcos and set out to implement principles of human rights and social justice. Among other things, Aquino created the Presidential Commission on Urban Poor (PCUP) with the aim to include the urban poor in policy and program development. The PCUP ensures that issues pertaining to the urban poor have a direct link (and therefore importance) to the President.

Importantly, there is a strong emphasis on urban land reform and housing in the Constitution. For example, Article XIII, Section 9, states:

The State shall, by law, and for the common good, undertake, in cooperation with the public sector, a continuing program of urban land reform and housing which will make available at affordable cost decent housing and basic services to underprivileged and homeless citizens in urban centers and resettlement areas. (Republic of the Philippines, 1987) 
The Constitution implements the principles of housing social justice in various acts, including the Urban Development and Housing Act of 1992 and the Comprehensive and Integrated Shelter Finance Act of 1994. The Urban Development and Housing Act mandates that affordable housing and services be made available to homeless urban citizens and for this process to be participatory in nature. Section 10 states:

Urban or rural poor dwellers shall not be evicted nor their dwellings demolished, except in accordance with law and in a just and humane manner. No resettlement of urban or rural dwellers shall be undertaken without adequate consultation with them and the communities where they are to be relocated. (Republic of the Philippines, 1987)

The Comprehensive and Integrated Shelter Finance Act is the basis for a "comprehensive and integrated shelter and urban development financing program by increasing and regularizing the yearly appropriation of the major components of the national shelter program" (Republic of the Philippines, 1994). The implementation of this act is the responsibility of a number of programs. One of these is the Community Mortgage Program (CMP):

[The CMP is] a mortgage financing program of the Social Housing Finance Corporation... which assists legally organized associations of underprivileged and homeless citizens to purchase and develop a track or land under the concept of community ownership. The primary objective of the program is to assist residents of blighted areas to own the lots they occupy, or where they choose to relocate to and eventually improve their neighbourhood and homes to the extent of their affordability. (Republic of the Philippines Bureau of Internal Revenue, 2021)

The CMP is administered by the Social Housing Finance Corporation and consists of three stages: land purchase, site development, and house construction (Social Housing Finance Corporation, 2021). The CMP has resulted in "noticing that the sequence of planningservicing-building-occupation (which contributes to making land scarce and expensive) has been replaced by incremental improvement of housing quality and infrastructure-mostly done by the main occupants" (UN-Habitat, 2018, p. 52). Regarding service delivery, the Local Government Code of 1991 was created to delineate the responsibility of delivering basic services to local governments: "It aimed to enhance provision of services in the grass roots level as well as improve the efficiency in resource allocation. Further, it sought to widen the decision-making space by encouraging the participation of stakeholders, especially in the local level" (Republic of the Philippines, 1991, p. 1).

\subsection{Local and Global Actors and Influences}

A variety of global actors, forces, and factors shape the Philippines policy environment. For example, UN-Habitat, UNESCO, and the Global Land Tool Network serve as nodes for knowledge mobilization. Through the Millennium Development Goals (MDGs) and the Sustainable Development Goals (SDGs), the UN System provides the conceptual framework for collective action, in particular by creating avenues for state, civil society, and private sector actors to pursue common interests. The MDGs and SDGs, moreover, provide an entry point for global and local civil society actors to press governments to hold to commitments they have made under various UN covenants and agreements. There are multiple civil society actors who represent and work closely with informal settlement dwellers and the urban poor to secure tenure. Pertinent to this study is SDI, which is an organisation consisting of a network of "communitybased organisations of the urban poor in 32 countries and hundreds of cities and towns across Africa, Asia and Latin America" (SDI, 2021). The organisations that make up the SDI network all work at the local level and rely on a peer-to-peer learning model with an overall goal to secure safe, suitable housing through inclusive processes.

At the national level, the two most important NGOs are the (HPFPI) and the Technical Assistance Movement for People and Environment Inc. (TAMPEI). Each of these entities operate as umbrella organizations, representing the interests of thousands of CBOs, while also providing human, technical, and financial resource support and capacity building. The HPFPI:

Brings together low-income community organizations from cities across the Philippines all engaged in finding solutions to problems they face with secure land, housing, income, infrastructure, health, welfare and access to affordable credit....The common denominator throughout the Philippines Homeless People's Federation is savings. The money which people save together creates a revolving community fund from which members can take loans for their small enterprises, for emergencies and day-to-day needs and for improving their houses. Members also save for land and housing in special housing savings accounts and many take part in community-based health care schemes. (HPFPI, 2001, p. 73)

While the post-Marcos and post-Cold War era has witnessed the emergence of an enabling environment for improving the lives of the poor and marginalized in the Philippines, one should be under no illusions regarding the complexity and scale of the challenge. For example, according to UN-Habitat (2018, p. 54):

Some obstacles remain for effective access of NGOs and civil organizations to the Local Development Councils. Many local governments have been slow to 
comply with UDHA provisions, especially regarding urban poor affairs offices. Even when NGOs and civil organizations are represented at local government level, their influence ability is very limited.

\section{Case Study: Secure Land Tenure as Basis for Climate Security?}

People who live informally, often referred to as "squatters" or "slum dwellers," experience dual vulnerabilities: one is to eviction and the other is to natural hazards, which are increased by climate change. These vulnerabilities are mutually reinforcing, with residents unable to coordinate actions and make investments upon land that does not belong to them. Efforts undertaken within the Philippines and elsewhere in the world by organizations such as SDI, HPFPI, and TAMPEI show that this precarious existence can be mitigated by land ownership. As shown below, land ownership presents opportunities for accessing human, financial, and technical resources otherwise not available to squatters.

For several decades, people in Sitio Libis lived informally on the privately-owned land, meaning they had no legal entitlement to living there and were constantly threatened with eviction. In 2010, the landowner, a bank, told the community that they had one year to purchase the land for 30 million Philippine pesos (approximately 64,000 USD) or else they would be evicted from the land. Motivated by the concern of being evicted, a group from the community contacted local government authorities for assistance. Members of the community sought help from their local congressman and local government authority; however, since they were an informal area, they did not qualify for any of the government programs designed to help the poor. The group searched for organisations who are helping the poor on the internet and sent letters to ten organisations asking for help. One of these organisations was the HPFPI, which was the only organisation that responded to the letters sent by residents of Sitio Libis. Theresa Carampatana was one of the leading women who initiated this process and is currently the president of the HPFPI. She stated during the interview process:

We went to the local government authority, but they didn't have the funds to finance [this] and the government money could not be spent on privately owned lands. So nobody was really helping us....We asked our congressman if he [could] shed out from his budget a little amount [to] help us buy the land and he said no, he [could] not spend any government money on us. And so we were left, you know, we didn't have any help, so we searched on the internet. We googled "organisations who are helping the poor" and then there were lists - a lot of organisations who are helping the poor-so we wrote letters to those organisations. We called them and said: "Hello, we are informal settlers in Valenzuela, we need help, how can you help us?" There were ten organisations who we called but only Homeless [HPFPI] came back to us and said: "We can talk."

The group searched the internet to learn about the work that HPFPI was engaged in. They found a video that told the story of another informal community in the region, Payatas, which used community savings to purchase and then upgrade the land they were living on. This video can be found on the HPFPI YouTube webpage. Theresa Carampatana, key informant, commented:

We already saw the video of the people in Payatas who are doing savings and that Father Roberto was helping and then the international community recognized them and then there were a lot of projects they did using their savings and so we thought, you know, maybe this group can help us also. If they can help the poor people in Payatas, why can't they help us?

Representatives from HPFPI taught the group about how other informal communities used community savings to purchase and then upgrade their own neighbourhoods. Initially the people within Sitio Libis were hesitant to embark on community savings because they feared that the HPFPI would steal their money. Trust was slow to develop; however, they eventually realized that this was their only strategy for purchasing the land. So, the people of Sitio Libis formed the ULHOA and began a community savings program. The initiative was launched with a ceremony whereby community members dropped five peso coins into a coin bank that was shaped like a house. They saved a million pesos after a year:

In the start we saved 50 pesos per month but then we went to the community and said: "If we only save 50 pesos it will take us 13 years before we can pay the down payment of 2.5 million." We asked them: "How do you want to go about this? What do you want to do? Do you want to spend the next 13 years saving 50 pesos if you can save 500 or 1000 pesos so the saving terms will become shorter, and that we can pay the bank right away... because the bank cannot wait....They gave us a year to pay. (Theresa Carampatana, key informant interview)

After the community saved 1.5 million pesos it returned to the HPFPI for help. Only after demonstrating their own capacity to save money was the community then able to apply to HPFPI for funding. Their proposal was successful; they were awarded another 1.5 million pesos:

They [HPFPI] asked us to prepare a loan proposal and then it was discussed in the community....The community agreed we take a loan....We submitted the proposal to Homeless... and then they gave us a 1.5 million loan because we are doing savings... and so the combined-our savings and the loan-we paid 
the bank the $10 \%$ down payment that started it all. (Theresa Carampatana, key informant interview)

The community then had the $10 \%$ down payment that the bank required for a mortgage to purchase the land. It was also able to negotiate for a loan through the CMP:

For 25 years we were saying we would buy the land....We were saying we would save, but we don't have money. They won't listen to us unless we pay a $10 \%$ down payment for the land. (Theresa Carampatana, key informant interview)

After making the down payment the bank and the community signed a Memorandum of Understanding (MOU), which was a requirement to obtain financing through the National CMP. It took two years for their application to the CMP program to be processed:

Actually [it takes] one year but our land was very complicated. We have a transmission line-a danger zone-across the land that we wanted to buy. So it was a very complicated situation. We had to divide the land, separate the danger zone outside the CMP area. So we could take a loan from the government for the area that is not in the danger zone. So it took us longer-a longer process. (Theresa Carampatana, key informant interview)

The community obtained funding through the CMP. The landowner (the bank) was paid in full (22.5 million pesos) by the government through the CMP. The original title was changed to the ULHOA. The community originally agreed to pay back the loan over 25 years (although they have decided to increase the payments so that the loan could be paid back sooner, also paying less interest on the loan):

Our members are $50 / 60$ years old so they don't want to pay the loans until they are 75 , so we said if they want to repay in a much lower and a lesser interest rate you should pay at least double of the minimum payment, because some of our members are paying 350-450 pesos per month but they can actually pay 500 or 600 pesos, so it would be lesser years paying back. (Theresa Carampatana, key informant interview)

The process involved many community meetings and considerable negotiation between community members. It was only after the community obtained secure tenure that they could systematically and collectively address the common hazards and vulnerabilities that threatened their safety and security. Prior to land ownership, community members simply coped with the flooding by waiting for the water to decrease. The floods often stayed for up to an hour before they would decrease again. Homeowners moved items to the second floor (if they had one) or piled items close to the ceiling of their dwellings. Homeowners had to stand on chairs or try to get as high as they could until water decreased. When there were fires community members had to collectively put fires out and people were severely injured or died. Once infrastructure was put into place (for example, proper drainage and pipes for excess water) the hazards associated with living on the land were lessened.

\subsection{Building Back Better: Climate Vulnerability and Adaptation}

Typical of informal settlements everywhere, Sitio Libis has long existed without access to municipal services. In a monsoonal environment, the absence of proper drainage compounds problems of a lack of sanitation services and the porosity of makeshift housing:

After thirty minutes of intense rain, the community would be flooded up to the knees or waist and we would have to put all of our valuables close to the ceiling. (Theresa Carampatana, key informant interview)

The electricity for the community also consists of an array of wires that would spark when the extreme rains arrived:

The wires would heat up, there would be shortages, sparks would occur, and fires would start. (Key informant 2)

The streets within the informal settlement were also very narrow, which meant that emergency vehicles such as ambulances and fire trucks could not get into the community to put out fires and to help victims of the storm. Only after the community purchased the land could it request financial and technical expertise from the government to assist with adaptation measures.

Before owning the land, the government did not respond to our requests for help to prevent and cope with these issues. As informal settlers we didn't have rights to right of way, drainage, outflow. However, after we owned the land we were able to obtain help from the government to improve the conditions in the settlement. (Key informant 3)

The ULHOA held community meetings to decide how to manage the extreme flooding that occurred in their area. The decision was made to obtain help through TAMPEI, which is the technical arm of the HPFPI. TAMPEI consists of young architect, engineering, and planning professionals who assist with community-led projects to improve housing, upgrade communities, map settlements, and embark on various planning initiatives (TAMPEI, 2019).

The community worked with TAMPEI to develop an integrated management plan that included improving drainage, solid waste management, widening of the main thoroughfare and home upgrading, including 
improved electrical connections (TAMPEI, 2019, p. 28). Known as "re-blocking," the process reformats and restructures the spatial layout of a settlement to optimize drainage, increase width of streets so that emergency vehicles can pass, and optimize the configuration of a slum (Brelsford et al., 2019).

The re-blocking process would require the "slashing" of houses to make rooms for widening the roads. This was a negotiated process, managed by the community and minimizing relocation and disruption. It was a slow process to start as regulations require access roads to be six metres in width. Widening the roads would significantly reduce the housing space of many residents. Eventually the city government agreed to reduce the road width requirement to four metres on condition that fire hydrants be installed at strategic locations along the route. Amending the law took four years and it was another three years before the re-blocking process began (TAMPEI, 2019).

With support from the HPFPI and TAMPEI, UHLOA was able to obtain 15 million pesos from the National Government to assist with the re-blocking process. This assisted with the relocation of those who lost their homes due to the widening of the street (Libis donated land and the government paid for the building of the new homes):

Without the trust accumulated during planning and in savings groups it would have been hard to convince people to remove part of their home for road widening or for making space for other [community] members. (Theresa Carampatana, key informant interview)

When speaking with homeowners who lost a section of their homes, we were told that they understood that it was important in order to widen the road so that emergency services can access the settlement and so proper drainage and electricity can be installed. Community members collaborated so that everyone would be able to have a home. In one case, a homeowner allowed for part of their own home to be knocked down to build a structure for another very low-income member. Ultimately, drainage to remove flooding and the wiring to prevent fires were both improved as part of the re-blocking process. Progress on re-blocking has been slow. By 2019, 27 houses had been re-blocked along the main road (TAMPEI, 2019). According to one community member, "the dialogue between the City and the community demonstrated that negotiations on land housing rights can be done in a peaceful manner, where both parties are on a win-win solution" (as cited in TAMPEI, 2019, p. 33).

\section{Discussion}

The belief that citizen-led, community-based approaches to community development will result in positive, sustainable development continues to dominate commu- nity planning literature (Dale et al., 2020; Hidalgo et al., 2021; Lang et al., 2020; Westoby et al., 2020). There is a very long history of support for this type of participatory method of development-starting in the 1960s with individuals such as Jacobs (1992) and Arnstein (1969) who argued that communities benefit when they have control over outcomes. This is in stark contrast to the top-down models imposed by planners such as Robert Moses and Ebenezer Howard, who believed that one master plan created by an expert could create what they knew was best for the public. The birth of community-based action in the Global South first occurred in rural areas; however, throughout the 1980s and 90s, as urban areas began to grow in population, the community-based approach shifted to address the challenges created by the growth of slums. Slum-upgrading is not the sole focus of participatory urban development. Ideas such as climate resilience and the green economy also are anchored in community-based approaches (Hidalgo et al., 2021). Put differently, the need to address climate change has created space for local communities to build resilience at a variety of geographical scales. There is recognition that responses to issues such as the heat island effect, flooding, and drought can be community-scale through projects such as softening pavements, creating urban parks, and tree planting. Thus, there is space for central planning and community-based planning to integrate. Planners can work with community members to address locally relevant issues, including developing scenario plans for coping with future unknowns that climate changes bring.

Despite positive efforts, there continues to be tension between top-down versus bottom-up, citizen-led approaches. In response to this, various concepts have been developed to try to bridge the gap between expertled top down and citizen-led bottom up, with "the right to the city" being a dominant approach. The right to the city is interpreted in different ways: as a philosophical ideal (Lefebvre, 1968a), as a rallying cry (Slater, 2009), and as an instrumental and functional approach (UN-Habitat, 2018). Fainstein's “just city" concept turns on a search for a pragmatic outcome within the "socially just capitalist city."

The case study shows that citizens have skills that they can utilize to initiate transformational change within their communities. In the Sitio Libis case, the process of obtaining secure land tenure and upgrading occurred because people within the community first had the ability to conduct research on the internet to learn about the resources available to them. Community members learned about the programs available, conducted community savings, wrote funding proposals, and adjusted to challenges that emerged (such as understanding land use plans around danger zones and negotiating mortgage requirements). Community leaders also established a network through the HPFPI and others who could support their work and provide consultation on navigating the administrative components of purchasing the land 
and improving their settlement. Evidently there are internal strengths and assets that community members hold that outsiders may neglect to acknowledge because people who live in informal settlements are often viewed derogatorily, as "slum dwellers" (with the negative connotations that come with that term).

The case study shows clearly that community-based approaches can result in positive change; however, this case demonstrates that these actions do not occur alone. Low-income communities require support for major change to occur. In this case, positive community change occurred with the help of NGOs, government actors, and the private sector. A broader lesson, then, is that governments must have supportive laws, policies, plans, and principles in place to support the urban poor. Indeed, the Philippines exemplifies this type of enabling governmental environment. Efforts to improve conditions for the urban poor have been in place since Aquino gained presidential power in 1986 and set in motion the significant reforms described above. This revolutionary change tipped the balance in populist fashion toward the poor with the PCUP exemplifying this shift in government thinking and practice.

Regarding equitable climate change planning, this case shows that the language of climate change has not been used to foster citizen engagement; but in the future it could be a building block for a public-privatecommunity partnership. Importantly, this case demonstrated that successful CBA resulted from state-civil society private sector cooperation and collaboration. This aligns with Fanstein's "just city" perspective, that the people of Sitio Libis worked within the existing system (however unfair it may be at a macro scale) and not against it (in pursuit of some imagined utopia) for specific, short- and medium-term, community-scale gains.

Clearly, the actions taken by the community of Sitio Libis were self-mobilising (Pretty, 1995). Faced with a series of natural (flood, fire) and social (the threat of eviction) challenges, they initiated the process by taking action independent of external agencies to create change. At the same time, in order to purchase their land and conduct re-blocking, citizens utilised the support systems and programs government and civil society organizations made available to them.

\section{Conclusion}

As stated in the methodology, this project intended to bring informal settlement dwellers from Sierra Leone to the Philippines to learn how they could utilise community savings to secure tenure and improve their communities. Clearly, international (i.e., SDI), national (i.e., HPFPI), and local (ULHOA) groups perceive the case study as a success story worthy of emulation. Certainly, there are replicable elements not unique to this small community. Indeed, the community savings approach is well established in international development practice, as is the practice of re-blocking. There are also gen- eral lessons to learn, as stated by the people of Sitio Libis themselves:

In the end, as the residents of ULHOA put it, they see massive mobilization, organizational unity, effective communication, transparent and fair leadership as critical elements needed to win against the challenges they are currently facing. Furthermore, they highlight the urgent need to educate their fellow members, and other poor groups in general, about legitimate approaches to land and housing rights. (TAMPEI, 2019, p. 34)

As shown here, participatory approaches are necessary and valuable and positive outcomes are possible when the state plays an enabling role. Given the magnitude of the challenges being created by climate change, it seems doubtful that CBA can be scaled up enough to build resilient cities. Despite this pessimistic conclusion, the struggle for the right to the city will no doubt continue, neighborhood by neighborhood.

\section{Acknowledgments}

The author would like to thank the Coady International Institute and Slum Dwellers International for funding and supporting this work. She would also like to thank Skye Dobson, formerly with Slum Dwellers International, and Ma. Theresa Carampatana, from the Homeless People's Federation of the Philippines Inc., for their roles in this project.

\section{Conflict of Interests}

The author declares no conflict of interests.

\section{References}

Appadurai, A. (2002). Deep democracy: Urban governmentality and the horizon of politics. Political Culture, 14(1), 21-47.

Arnstein, S. (1969). A ladder of participation. Journal of the Institute of Planners, 35(4), 216-224.

Brelsford, C., Martin, T., \& Bettencourt, L. (2019). Optimal reblocking as a practical tool for neighbourhood development. Environment and Planning B: Urban Analytics and City Science, 46(2), 303-321.

Brenner, N., \& Theodore, N. (2002). Cities and geographies of actually existing neoliberalism. Antipode, 34(3), 349-379.

Brown, A. (2013). The right to the city: Road to Rio 2010. International Journal of Urban and Regional Research, 37(3), 957-971.

Bündnis Entwicklung Hilft. (2018). World risk report 2018. BEH and Ruhr University Bochum - Institute for International Law of Peace and Armed Conflict.

Castells, M. (1983). The city and the grassroots: A crosscultural theory of urban social movements. University 
of California Press.

Chambers, R. (1983). Rural development: Putting the last first. Wiley.

Cornwell, A. (2008). Unpacking "participation": Models, meanings and practices. Community Development Journal, 43(4), 269-283.

Dale, A., Vella, K., Ryan, S., Broderick, K., Hill, R., \& Brewer, T. (2020). Governing community-based natural resource management in Australia: International implications. Land, 9(7).

Dodman, D., \& Mitlin, D. (2013). Challenges for community-based adaptation: Discovering the potential for transformation. Journal of International Development, 25, 640-659.

Eckstein, D., Künzel, V., \& Schäfer, L. (2021). Global climate risk index 2021. Germanwatch.

Fainstein, D. (2009). Planning and the just city. In P. Marcuse, J. Connolly, J. Novy, I. Olivo, C. Potter, \& J. Steil (Eds.), Searching for the just city: Debates in urban theory and practice (pp. 19-39). Routledge.

Gonsalves, J., Becker, T., Braun, A., Campilan, D., De Chavez, H., Fajber, E., Kapiriri, M., Rivaca-Caminade, J., \& Vernooy, R. (Eds.). (2005). Participatory research and development for sustainable agriculture and natural resource management: A sourcebook. Volume 1: Understanding participatory research and development. CIP-UPWARDS, IDRC.

Government of the Philippines. (2021a). Climate change impacts. National Integrated Climate Change Database and Information Exchange System. https:// niccdies.climate.gov.ph/climate-change-impacts

Government of the Philippines. (2021b). Home. https:// www.gov.ph/es.html

Hansen, B. T., \& Stepputat, F. (2001). Introduction: States of imagination. In B. T. Hansen \& F. Stepputat (Eds.), States of imagination: Ethnograhic explorations of the postcolonial state (pp. 1-38). Duke University Press.

Harvey, D. (1985). The urbanization of capital. The Johns Hopkins University Press.

Hidalgo, D. M., Nunn, P. D., Beazley, H., Sovinasalevu, J. S., \& Veitayaki, J. (2021). Climate change adaptation planning in remote contexts: Insights from community-based natural resource management and rural development initiatives in the Pacific Islands. Climate and Development. Advance online publication. https://doi.org/10.1080/17565529. 2020.1867046

Holland, J., \& Blackburn, J. (1998). Whose voice? Participatory research and policy change. Intermediate Publications.

Homeless People's Federation. (2001). Meet the Philippines Homeless People's Federation. Environment and Development, 13(2), 72-84.

IPCC. (2014). Asia. https://www.ipcc.ch/site/assets/ uploads/2018/02/WGIIAR5-Chap24_FINAL.pdf

IPCC. (2020). The regional impacts of climate change: An assessment of vulnerability. https://www.ipcc.ch/ report/the-regional-impacts-of-climate-change-anassessment-of-vulnerability

Jacobs, J. (1992). The death and life of great American cities. Penguin Random House.

Kemmis, S., McTaggart, R., \& Nixon, R. (2013). The action research planner: Doing critical participatory action research. Springer.

La Viña, T. (2017, March 28). Duterte and the urban poor. Manilastandard. https://manilastandard.net/ opinion/columns/eagle-eyes-by-tony-la-vina/ 232897/duterteand-the-urbanpoor.html

Lang, R., Chatterton, P., \& Mullins, D. (2020). Grassroots innovations in community-led housing in England: The role and evolution of intermediaries. International Journal of Urban Sustainable Development, 2(1), 52-72.

Lefebvre, H. (1968a). Everyday life in the modern world. Transaction.

Lefebvre, H. (1968b). Le droit à la ville [The right to the city] (2nd ed.). Anthropos.

Marcuse, P. (2009). From critical urban theory to the right to the city. City, 13(2/3), 185-197.

Mathie, A., \& Cunningham, G. (Eds.). (2008). From clients to citizens: Communities changing the course of their own development. Intermediate Technology Publications.

Mitchell, D. (2003). The right to the city: Social justice and the fight for public space. Guildford Press.

Ninglekhu, S., \& Rankin, K. (2017). The urban poor: The urban majority and everyday life. In A. L. Bain \& L. Peake (Eds.), Urbanization in a global context (pp. 245-259). Oxford University Press Canada.

Park, R. E., Burgess, E. W., \& McKenzie, R. D. (1925). The city. University of Chicago Press.

Philippines Statistics Authority. (n.d.). Home. https://psa. gov.ph/grdp

Porio, E. (2014). Climate change vulnerability and adaptation in Metro Manila. Asian Journal of Social Science, 42, 75-102.

Pretty, J. N. (1995). Participatory learning for sustainable agriculture. World Development, 23(8), 1247-1263.

Ravallion, M., Chen, S., \& Sangraula, P. (2007). New evidence on the urbanization of global poverty. Population and Development Review, 33(4), 667-701.

Reid, H., Alam, M., Berger, R., Cannon, T., Huq, S., \& Milligan, A. (2009). Community-based adaptation to climate change: An overview. IIED. https://pubs.iied. org/sites/default/files/pdfs/migrate/G02608.pdf

Republic of the Philippines Bureau of Internal Revenue. (2021). Community Mortgage Program (CMP). https://bit.ly/3ogvSU0

Republic of the Philippines. (1987). The Constitution of the Republic of the Philippines. https://www.official gazette.gov.ph/constitutions/1987-constitution

Republic of the Philippines. (1991). Local government code. http://legacy.senate.gov.ph/lisdata/ 82027399 !pdf

Republic of the Philippines. (1994). Comprehensive and 
integrated shelter financing act of 1994 (Republic Act No. 7835). https://bit.ly/3kQgETz

Roy, A. (2009). The 21st-century metropolis: New geographies of theory. Regional Studies, 43(6), 819-830.

Sassen, S. (1991). The global city: New York, London, Tokyo. Princeton University Press.

Sassen, S. (2002). Global networks, linked cities. Routledge.

SDI. (2021). Who is SDI? https://sdinet.org/who-is-sdi/ about-us

Simone, A. M. (2005). The right to the city. Interventions, $7(3), 321-325$.

Simone, A. M. (2008). The politics of the possible: Making urban life in Phnom Penh. Singapore Journal of Tropical Geography, 29(2), 186-204.

Simone, A. M. (2010). City life from Jakarta to Dakar: Movements at the crossroads. Routledge.

Slater, T. (2009). Missing Marcuse: On gentrification and displacement. City, 12(2/3), 293-311.

Smith, N. (1979). Toward a theory of gentrification: A back to the city movement by capital, not people. Journal of the American Planning Association, 45(4), 538-548.

Smith, N. (1984). Uneven development. Blackwell.

Social Housing Finance Corporation. (2021). Social housing finance corporation. https://www.shfcph.com/ Mandate.html

Tadiar, N. (2013). Lifetimes of disposability in global neoliberalism. Social Text, 31(2), 19-48.

Technical Assistance Movement for People and Environment, Inc. (2019). iSiyudad: Selected narratives of HPFPI communities in asserting their right to the city. TAMPEI.

Teodoro, J. I. E., \& Rayos Co, J. C. (2009). Communitydriven land tenure strategies: The experiences of the Homeless People's Federation of the Philippines. Environment and Urbanization, 21(2), 415-441.

Titz, A., Cannon, T., \& Kruger, F. (2018). Uncovering "community": Challenging an elusive concept in development and disaster related work. Societies, 8(3). https://doi.org/10.3390/soc8030071

UN-Habitat. (2018). Alternative solutions to forced evictions and slum demolitions: Case studies from Africa, Asia, North and South America. UN Human Settlements Programme.

Westoby, R., McNamara, K. E., Kumar, R., \& Nunn, P. D. (2020). From community-based to locally led adaptation: Evidence from Vanuatu. Ambio, 49, 1466-1473.

White, S. (1996). Depoliticising development: The uses and abuses of participation. Development in Practice, 6(1), 6-15.

World Bank. (2021). Philippines economic update, December 2020: Building a resilient recovery. https:// openknowledge.worldbank.org/handle/10986/ 34899

\section{About the Author}

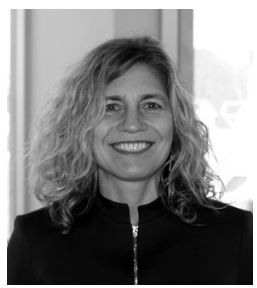

Corrine Cash (PhD) is assistant professor of planning and community climate adaptation at Mount Allison University in Sackville, New Brunswick, Canada. Prior to this she spent four years leading the Building Community Resilience work at the Coady International Institute in Antigonish, Nova Scotia, Canada, and as an assistant professor in climate and environment at St. Francis Xavier University, Antigonish, Canada. She has a Master's in Environmental Studies (Planning) and a PhD in Planning from the University of Waterloo, Ontario, Canada. 